\title{
Bell Beaker Metallurgy and the Emergence of Fahlore-copper Use in Central Europe
}

\author{
Matthias B. Merkl* \\ Landesamt für Denkmalpflege im Regierungspräsidium Stuttgart, Archäologische Denkmalpflege, Berlinerstr. 12, 73728 Esslingen a. Neckar, \\ Federal Republic of Germany
}

\section{ARTICLE INFO}

\section{Article history:}

Received: 6 December 2010

Accepted: 21 January 2011

\section{Keywords:}

eastern Bell Beaker group

elemental composition

fahlore-copper

properties of copper

statistical grouping

\begin{abstract}
This paper aims to clarify whether there is a link between the emergence of fahlore-copper use and the Eastern Bell Beaker group. It attempts to shed light on the question of whether Bell Beaker users in central Europe had specific metallurgical expertise. A large database of trace element analyses is compared statistically, because the elemental composition of copper artefacts is affected by production process and the structure of the ore - and a similar occurrence within artefacts reflects a similar metallurgy.
\end{abstract}

\section{Introduction}

Several factors indicate that the Bell Beaker phenomenon is founded on social, economic and religious networks (Benz et al. 1998; Vander Linden 2007). Even in early Bell Beaker analyses, metallurgy has been considered a principal factor in the distribution of the Bell Beaker phenomenon (e.g. Childe 1929, 196). Most studies that examined the metallurgy of the Eastern Bell Beaker group have focused primarily on copper objects directly associated with Bell Beakers. These studies investigated the trace element composition of Bell Beaker related finds, either in connection with artefact typology, or in regard to the origin of the raw material (Kuna, Matoušek 1978; Matuschik 2004; Metzinger-Schmitz 2004).

Based on a wide range of Chalcolithic trace element analyses - not only those directly associated with Bell Beakers - this paper aims to explain whether there was specific Bell Beaker metallurgy. ${ }^{1}$ It attempts to clarify the

\footnotetext{
"Corresponding author. E-mail: Matthias.Merk1@rps.bwl.de
}

${ }^{1}$ This paper arose from aspects of my doctoral thesis "Bell Beaker copper use in central Europe: a distinctive tradition? A re-evaluation of the composition of copper artefacts and its effects on the properties of the metal" at the University of Edinburgh. The thesis was examined by Prof. Dr. R. Mercer and Prof. Dr. B. S. Ottaway in May 2010. technological purpose for a broader use of fahlore-coppers - copper types that contain significant levels of several impurities such as arsenic, antimony, silver and nickel during the $3^{\text {rd }}$ millennium BC. Finally, it tries to shed light on the role Bell Beaker communities may have played in distributing this technology throughout central Europe.

\section{The archaeological evidence of Bell Beaker metallurgy}

Because metal objects are frequently discovered in association with Bell Beakers, the Bell Beaker phenomenon has often been linked to metallurgy. The association of copper and gold artefacts, such as tanged daggers, awls and spiral finger rings, in single graves indicates that these objects symbolised a higher status of the buried person and the exceptional value of the goods (e.g. Heyd 2007; Vander Linden 2007; Zimmermann 2007, 122 ff.).

Apart from metal artefacts, objects used as metalworking tools have also been discovered in association with Bell Beakers. This supports the hypothesis that the Bell Beaker phenomenon is linked to metal work. Metal analyses and experimental archaeology successfully demonstrated that cushion stones and stone axes are in fact metal workers' 


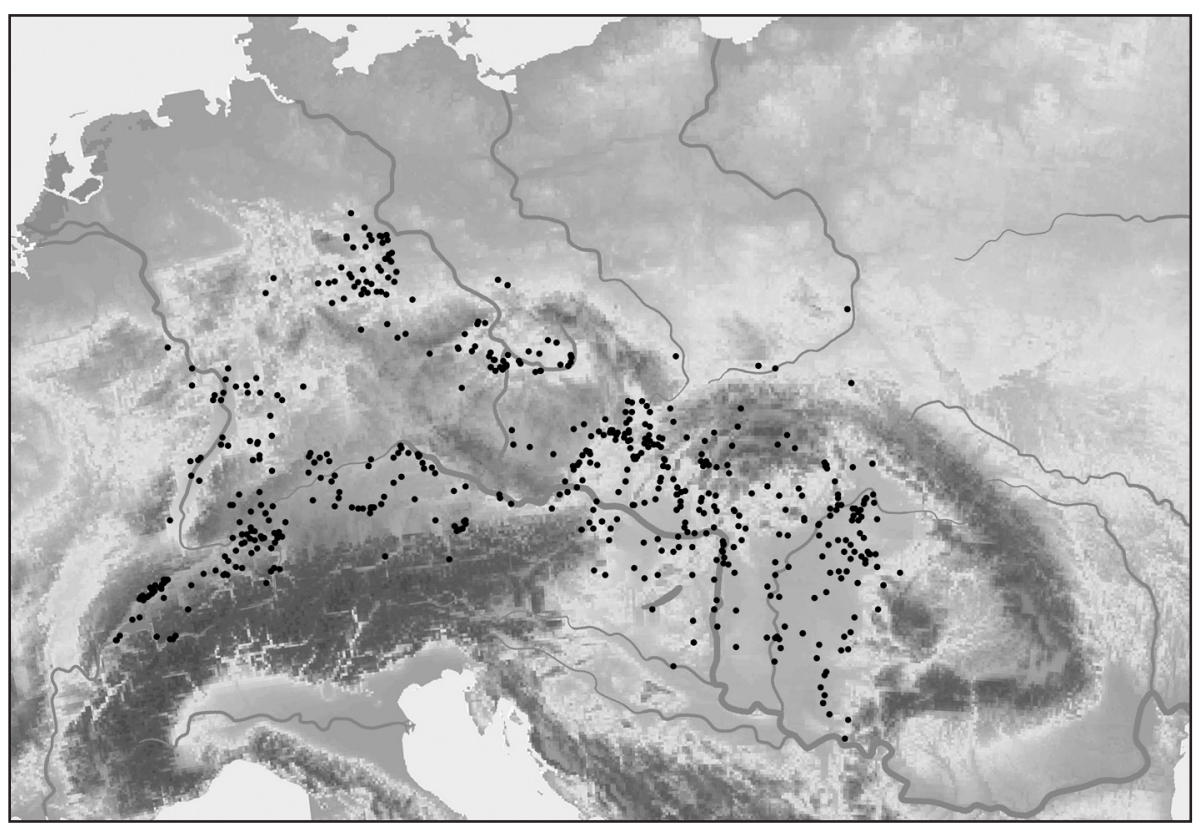

Figure 1. Sites from which copper objects were analysed.

tools (cf. Butler, van der Waals 1966; Bertemes et al. 2000; Bertemes, Heyd 2002; Freudenberg 2009).

In spite of certain regional variations in artefact types indicative of the entire Bell Beaker phenomenon is the fact that metal or metallurgy related finds seem to express a value or importance for people who were "supporters" of the Bell Beaker ideology. Whilst in central Europe copper metallurgy was common for about 1,000 years prior to the emergence of Bell Beaker, in north-western Europe the introduction of metallurgy was likely connected with the Bell Beaker phenomenon, as both emerge for the first time in archaeological contexts that are dated more or less contemporaneously. This assumption is also based on the usage of specific types of Bell Beaker metal in this region (Butler, van der Waals 1966; Needham 2002).

The presence of both metal work and Bell Beakers indicate a connection between metallurgy and the Bell Beaker phenomenon in the Iberian Peninsula (Rovira Llorens, Delibes de Castro 2005, 513 f.). In central Europe only one mould has been found in a Bell Beaker context. This mould is exclusive, direct evidence of Bell Beaker metal working, and was used for casting typical Bell Beaker tanged daggers ${ }^{2}$. Whether a linkage between metallurgy and the Bell Beaker phenomenon also existed in central Europe is yet to be verified. Due to the lack of direct evidence of metal work it is necessary to employ other methods. In this regard the archaeological significance of trace element analyses could be consulted.

${ }^{2}$ The sandstone mould was discovered in a Bell Beaker grave at Ludérov (CZ). It was an extraordinary grave that contained also nine Bell Beakers and a copper awl (Hajek 1966, 214).

\section{Trace element composition and their effects on the properties of copper}

Subsequent research will concentrate on a review of published trace element analyses of copper objects ${ }^{3}$. Based on a selection of 1,943 trace element analyses of copper finds from central Europe, mainly southern and central Germany, Bohemia, Moravia and the Carpathian basin (Figure 1), dated between around 4500 and $2000 \mathrm{BC}$, this paper aims to clarify whether people connected to the Eastern Bell Beaker group used distinctive types of copper that distinguishes the metal work of this community from other archaeological groups.

In order to account for all possible influences on the metallurgical expertise of Bell Beaker metal workers this study considers trace element analyses of the earliest copper objects in the Carpathian basin, as well as the copper objects of the Earliest Bronze Age - a phase that overlaps with the Bell Beaker phase. Whereas the earliest copper artefacts appeared in the Carpathian basin in the $5^{\text {th }}$ millennium $\mathrm{BC}$, tin-bronze was well established by around 2000 BC (Roberts et al. 2009). Since only copper metallurgy is examined here the database excludes tin-bronze artefacts that contain more than $4.5 \% \operatorname{tin}^{4}$.

${ }^{3}$ A detailed catalogue of the entire database would exceed the framework of this paper and is not included. A comprehensive catalogue will be published shortly. Most of the selected trace element analyses have been published by Junghans et al. (1960; 1968 \& 1974), Ottaway (1982), Krause (1988 \& 2003), Frana et al. (1995) and Bartelheim et al. (2002).

${ }^{4}$ It has not been clarified whether there is a specific threshold marking the difference between naturally tin-bearing copper and copper deliberately alloyed by tin - so-called tin-bronze. Whilst before around $2000 \mathrm{BC}$ copper artefacts generally do not contain more than around 4\% tin, afterward copper artefacts contain significantly more than 4\% tin (e.g. Spindler 1971; Liversage 1994). 
Some early archaeometallurgical examinations used trace element analyses to locate the origin of copper ores (e.g. Otto, Witter 1952). However, several scholars have comprehensively demonstrated that it is impossible to draw conclusions about the raw material based solely on the elemental compositions of finished copper artefacts, since various metallurgical procedures (such as smelting, merging and recycling) influence the trace element compositions of objects, so that these do not correspond to the compounds found within the original ores (e.g. Friedman et al. 1966; McKerrell, Tylecote 1972; Sperl 1975). A possible provenance for copper can only be determined by combining trace element analyses with lead isotope analyses (e.g. Pernicka 1995, 99-105; 1999). Consequently, it is crucial to focus on other ideas of interpreting trace element analyses of prehistoric copper finds.

Previous material science investigations demonstrated that trace elements affect the physical and chemical properties of copper (e.g. Hofman 1924; Archbutt, Prytherch 1937; Dies $1967)^{5}$. In principle, trace elements soluble in solid copper affect the copper properties more positively, i.e. properties are improved in comparison with pure copper, because insoluble impurities (e.g. bismuth, iron or lead) often precipitate as an oxide that generally make copper brittle. However, soluble elements such as arsenic, nickel or silver, counteract the negative influences of bismuth and iron (Hanson, Ford 1924; 1927).

Bismuth is thought the most damaging impurity appearing commonly in copper. In combination with other elements, especially arsenic, this effect is neutralised (Hanson, Ford 1927; Junk 2003, 34). In the database of Chalcolithic trace element analyses used in this study there is not a single analysis that indicates that bismuth is either the only, or a dominating impurity of copper objects. Although lead also tends to cause brittleness, it does positively influence copper's smelting and casting properties by decreasing the solidification temperature - even at low concentrations (Dies 1967, 610).

Both nickel and silver have very similar chemical characteristics to copper (e.g. similar ionic radius, lattice constant and electro-negativity). They are readily soluble in copper and hardly influence coppers' properties (Archbutt, Prytherch 1937, 78; Dies 1967, 193, 783). The two elements make copper brighter - even silverish (Archbutt, Prytherch 1937).

The matter of tin is significant for archaeological studies as its intentional inclusion in copper forms bronze and marks the transition into a new prehistoric period linked with significant cultural change. However, this transition is connected to the emergence of a bronze alloy containing around 8 to $12 \%$ tin. In our case, we are dealing with copper

${ }^{5}$ Archbutt and Prytherch (1937) summarised various studies that investigated the effects of trace elements (e.g. arsenic, bismuth, iron, oxygen) on copper. In several volumes of the Journal of Metals, the results of the single studies were published in-depth by researchers involved in that project. Those primary studies will also be taken into account and referenced in later sections. objects bearing not more than $4.5 \%$ tin. Nevertheless, it is essential to look at copper that contains lower concentrations of tin. This is necessary, because alloys with 1 and $4 \%$ tin improve hardness, malleability and tensile strength (Dies 1967, 526; Lechtman 1996, 488). The addition of tin changes the colour from the typical copper-orange into a brownishred (from c. 3\% tin) (Dies 1967, 521).

Antimony precipitates in solid copper and causes brittleness comparable to bismuth (Dies 1967, 676; Smart 1970, 415). In combination with further "positive" elements, such as silver, nickel and/or arsenic, antimony improves the tensile strength, hardness, malleability and overall cold and hot working properties (Archbutt, Prytherch 1937, 115 ff.; Moesta 2004, 272; Junk 2003, 155 ff.).

Arsenic-bearing copper has often been discussed in archaeometallurgical literature (e.g. Ottaway 1978, Klassen et al. 1998; Matuschik 1998). The influence of arsenic on the properties of copper has been examined by Charles (1967), Lechtman (1996), Junk (2003) and especially Budd (1991). It has often been mentioned that arsenic makes copper harder - even as hard as copper with tin. Arsenic, however, is both extremely volatile and toxic. This may be why arsenical copper was not used more extensively in later times (Charles 1967). Whilst the mechanical properties of copper containing less than c. $2 \%$ arsenic are only slightly improved, more than $2 \%$ of arsenic in combination with other elements (e.g. antimony, silver, nickel) improves hardness, malleability, tensile strength and other working properties (Archbutt, Prytherch 1931, 284 ff.; Budd 1991, $132 \mathrm{f}$.). Because of the high volatility of arsenic (McKerrell, Tylecote 1972, 209), it is assumed that arsenic contraction within copper is intentional in order to change the properties of the copper (Ottaway 1982, 131).

Based on experiments, several studies claim that special casting and working techniques were used in order to improve the properties of prehistoric copper artefacts, whereby different copper types affect the workability of the material (e.g. Staniaszek, Northover 1983; Wang, Ottaway 2004; Kienlin 2008). Thus, it is noted that various types of fahlorecopper - copper containing significant amounts of several impurities, such as arsenic, antimony, nickel and silver - do have beneficial properties in comparison with other copper types (e.g. pure or low concentrated arsenical copper). The combination of the impurities arsenic, antimony and nickel are particularly beneficial to the mechanical and working properties of copper. Additionally, the effects of trace elements on the colour of copper may not be neglected, as this was likely a key indicator for prehistoric metalworkers when selecting the desired type of copper.

Even if the physical and chemical properties of copper motivated the choice of a particular type of copper, the accessibility of a specific resource was probably also influential (cf. Strahm, Hauptmann 2009, 121-124). The desire to obtain better types of copper (e.g. fahlore-coppers) may have lead miners to prospect and exploit new deposits. This study attempts to clarify whether the composition of Bell Beaker metal differs from copper found in association with other 


\begin{tabular}{|c|c|c|c|c|c|c|c|c|c|}
\hline & $\mathrm{SN}$ & $\mathrm{PB}$ & AS & $\mathrm{SB}$ & $\mathrm{AG}$ & $\mathrm{NI}$ & $\mathrm{BI}$ & $\mathrm{FE}$ \\
\hline & & Mean & Mean & Mean & Mean & Mean & Mean & Mean & Mean \\
\hline \multirow[t]{19}{*}{ Metal_groups } & Almost pure &, 0000 &, 0000 &, 0205 &, 0065 & 0115 & 0190 & 0004 &, 0002 \\
\hline & Almost pure with Iron & .0220 &, 0069 &, 0000 &, 0006 & 0067 &, 0634 &, 0024 & , 1209 \\
\hline & $\begin{array}{l}\text { Antimony-arsenic-copper } \\
\text { with Silver }\end{array}$ & ,0604 & ,0028 & ,6476 & 1,0110 & ,4922 & , 0147 & ,0460 & ,0003 \\
\hline & $\begin{array}{l}\text { Antimony-nickel-copper } \\
\text { (high) }\end{array}$ & 0195 & 4533 & 2,2083 & 6,6262 & 1,2008 & 3,5829 & ,0061 & 0824 \\
\hline & $\begin{array}{l}\text { Antimony-nickel-copper } \\
\text { (intermediate) }\end{array}$ & ,2327 & ,0666 & 9368 & 2,2837 & 7816 & 1,8639 & ,0060 & 1536, \\
\hline & $\begin{array}{l}\text { Antimony-nickel-copper } \\
\text { (low) }\end{array}$ & ,2510 & ,0284 & ,4315 & 1,1074 & ,4860 & 8271 & ,0025 & ,0138 \\
\hline & Antimony-silver-copper & ,0006 &, 0000 &, 0000 & ,4353 & ,1771 & 0010 & ,0292 & ,0003 \\
\hline & Arsenic-antimony-copper &, 0000 &, 0000 & 1,3686 & 1,2417 &, 5500 &, 0023 &, 1303 &, 0003 \\
\hline & Arsenic-copper (high) & 0317 & 2081 & 1,6896 & 0817 & ,1671 & ,2616 & 0586 & , 1080 \\
\hline & Arsenic-copper (low) & 0008 & 0072 & ,6932 &, 0283 &, 0320 & 0095 & 0037 &, 0543 \\
\hline & $\begin{array}{l}\text { Arsenic-copper with } \\
\text { Impurities }\end{array}$ & ,0528 & ,3804 & 8941 & 1679, & 1540 & 1132 & ,0277 & 1843, \\
\hline & Arsenic-lead-copper & 0062 & 8461 & 8096 & 0692 & 0690 & 0804 & ,1023 & , 0844 \\
\hline & Arsenic-nickel-copper &, 0000 &, 0025 & 1,7945 & .0955 & 0001 & 1,3027 & .0017 &, 0668 \\
\hline & Pure &, 0000 &, 0000 &, 0000 &, 0000 &, 0000 & ,0010 &, 0000 &, 0000 \\
\hline & Pure with Nickel &, 0000 & 0000 & 0000 &, 0000 & 0023 & ,1220 &, 0000 &, 0000 \\
\hline & Pure with Silver &, 0000 &, 0000 &, 0000 &, 0000 & ,0268 & ,0011 &, 0000 & .0000 \\
\hline & $\begin{array}{l}\text { Silver-antimony-copper } \\
\text { (high) }\end{array}$ & ,0437 & 1449 & 1619 & ,3528 & ,7913 & ,0393 & ,0256 & ,3927 \\
\hline & $\begin{array}{l}\text { Silver-antimony-copper } \\
\text { (low) }\end{array}$ & ,0001 & ,0000 & ,0107 & ,0893 & 1601 & ,0206 & ,0072 & ,0000 \\
\hline & $\begin{array}{l}\text { Tin-rich-copper (incl. Ag, } \\
\text { Sb etc) }\end{array}$ & 1,1125 & 1194, & 1458 & 2080 & 1540 & ,0836 & ,0052 & ,0415 \\
\hline
\end{tabular}

Figure 2. Mean values of the trace elements of the 19 metal groups.

archaeological groups (e.g. Corded Ware communities) in central Europe and if the distribution of fahlore-metallurgy is strongly connected with the Bell Beaker phenomenon.

\section{The definitions and descriptions of chalcolithic types of copper}

In order to compare and summarise the data from copper analyses, the dataset is grouped by compositions and metallurgical properties. Statistical grouping aims to ease the manageability and comparability of a large set of data. The database of 1,943 trace element analyses is evaluated using Two-Step Cluster Analysis ${ }^{6}$ and Principle Component Analysis ${ }^{7}$. Statistical grouping is carried out in consideration of trace elements that have been analysed by the respective projects and that significantly affect the properties of copper. Arsenic, antimony, bismuth, iron, lead, nickel, silver and tin are the eight trace elements that fulfil these conditions. The results of both statistical approaches are contrasted in order to find the most similar types of copper which are defined by their trace element composition.

Supported by the results of both statistical methods and accounting for statistical outliers five major copper groups

${ }^{6}$ The methodology and complexity of the Two-Step Cluster Analysis is described in-depth by Zhang et al. (1996\&1997), Chiu et al. (2001) and Bacher et al. (2004).

${ }^{7}$ Principle Component Analysis has been explained in several books concerning statistics in archaeology (e.g. Shennan 1997, 265-307; Baxter 2003, 73-83). can be distinguished in the dataset including (almost) pure, silver-dominated, tin-rich, arsenic-rich and antimony-rich. These major groups can be sub-divided into 19 more defined "metal groups" which differ in terms of the quality and quantity of impurities (Figure 2).

\section{Is there a distinctive Bell Beaker copper metallurgy in central Europe?}

Since a broader use of fahlore-copper can be dated to the $3^{\text {rd }}$ millennium BC (Krause 2003, 145), it follows that the Bell Beaker phenomenon which spread over Europe throughout that time was closely linked to that progress. The questions of whether there exists a typical Bell Beaker metal, and whether users of Bell Beaker pottery played an exceptional role in connection with the distribution of fahlore-metallurgy requires clarification.

The database of analyses carried out on Bell Beaker related copper finds consists of 82 trace element analyses carried out on 80 artefacts -62 dagger, 13 awls, two oar-headed pins with an S-profiled rolled head, two sheet metals and one flat axe $\mathrm{e}^{8}$ (Figure 3). No artefact-specific copper usage can be identified, simply because daggers are by far the most prevalent objects.

${ }^{8}$ The database contains two artefacts that have been analysed twice. These double-analyses are included in order to check possible outliers. However, for further interpretation they can be omitted, because in both cases the results are comparable. The two analyses of the awl from Ludeřov (CZ) are considered respectively as almost pure and pure copper with silver (differing only in trace amounts of silver and bismuth) and both of the tanged daggers from Mühlhausen "Aktivistenring" (D) are part of the metal group arseniccopper with impurities. 
With regard to the 1,943 trace element analyses of Chalcolithic finds from central Europe the Bell Beaker data set can be classified into 13 metal groups from the previously defined 19 groups (Figure 4). In the following section these groups will be described in comparison with the entire set of Chalcolithic data.

Nine trace element analyses are characterised as pure copper and almost pure copper that contain only traces of nickel or silver. These types of copper were used from the very beginnings of metallurgical activity in Europe. The heavy axes of the Hungarian Tiszapolgár and Bodrogkeresztúr group of the late $5^{\text {th }}$ and early $4^{\text {th }}$ millennium $\mathrm{BC}$, in particular, are made of rather pure types of copper, though these coppers were in use throughout the entire Chalcolithic period. These types of copper contain low levels of impurities that do not considerably influence the properties of the material in comparison with absolutely pure copper.

Seven copper daggers are characterised by dominant arsenic contents with small traces of other impurities (arsenic-copper [low] in Figure 4). This copper is typical for the $4^{\text {th }}$ millennium $\mathrm{BC}$ and has been discussed several times in archaeometallurgical research. Its high occurrence in artefacts found in Mondsee, Pfyn and Baden contexts has led to a comprehensive discussion (e.g. Ottaway 1982; Matuschik 1998). Metallurgical examinations have demonstrated that arsenic influences hardness, working properties and colour, but only at more than c. $2 \%$, and in combination with other inclusions such as antimony the improvements are remarkable (Budd 1991; Lechtman 1996).

Other types of copper that were used to produce Bell Beaker related objects can be generally categorised as forms of fahlore-copper, varying by quantity and quality of impurities. 65 of the 80 Bell Beaker copper objects consist of tin-rich or fahlore-coppers, which vary by dominant elements (antimony, arsenic, silver or tin) and significant
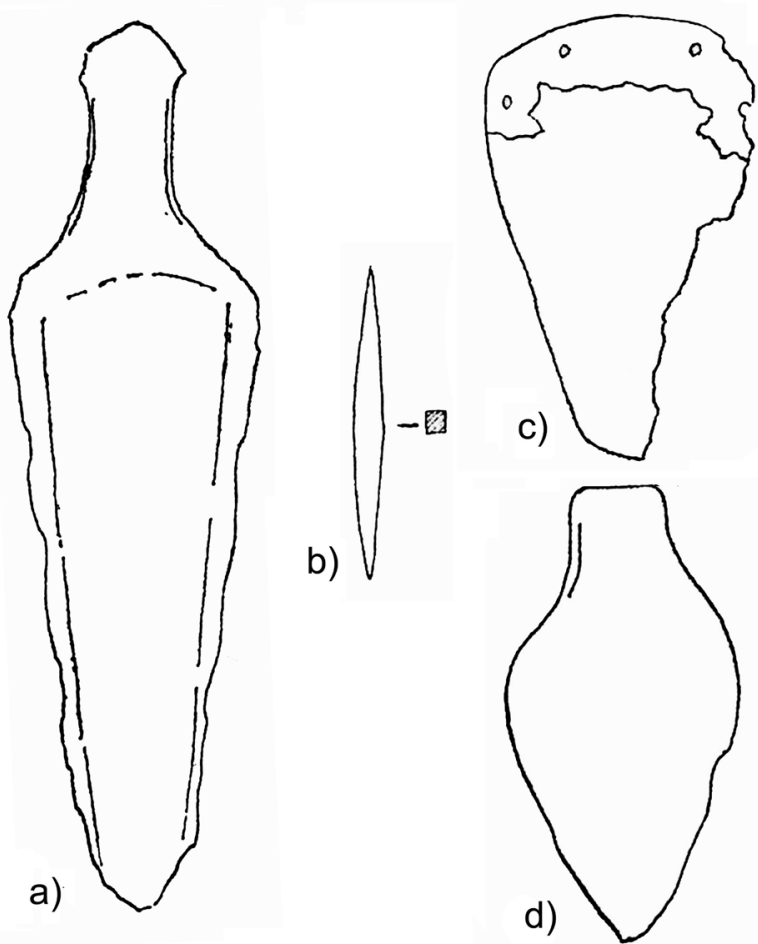

Figure 3. Samples of analysed Bell Beaker copper finds. a) Stehelčeves $(\mathrm{CZ}), \mathrm{b})$ Lysolaje $(\mathrm{CZ})$, c) Šlapanice $(\mathrm{CZ}), \mathrm{d})$ Thalmassing (D) (selected after Kuna, Matoušek 1978, Figures 1 \& 2).

concentrations of further impurities. These types of copper provide an overall improvement to both the mechanical and working properties. Fahlore-coppers, used commonly after c. $2800 \mathrm{BC}$, have improved properties that contrast to previously types. Higher levels of several trace elements are

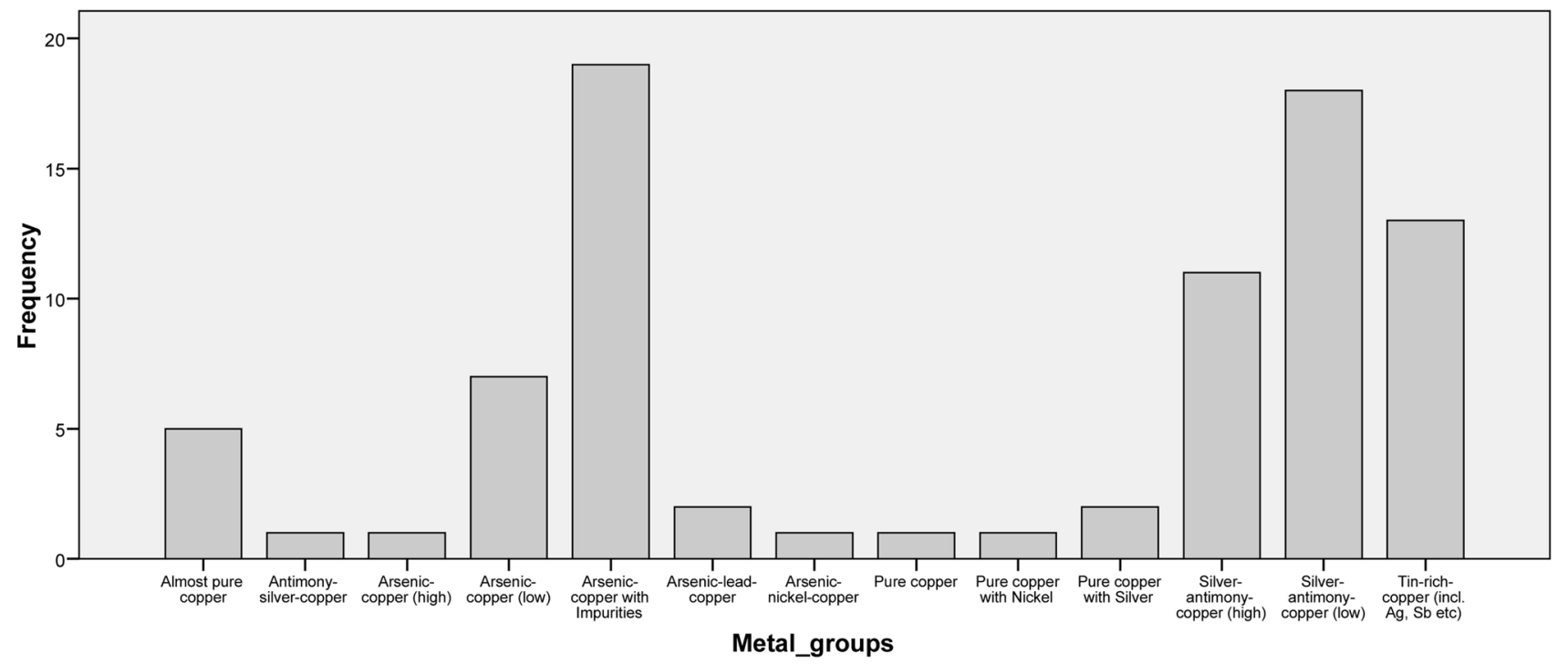

Figure 4. Absolute frequency of trace element analyses provide by Bell Beaker copper objects by metal group. 


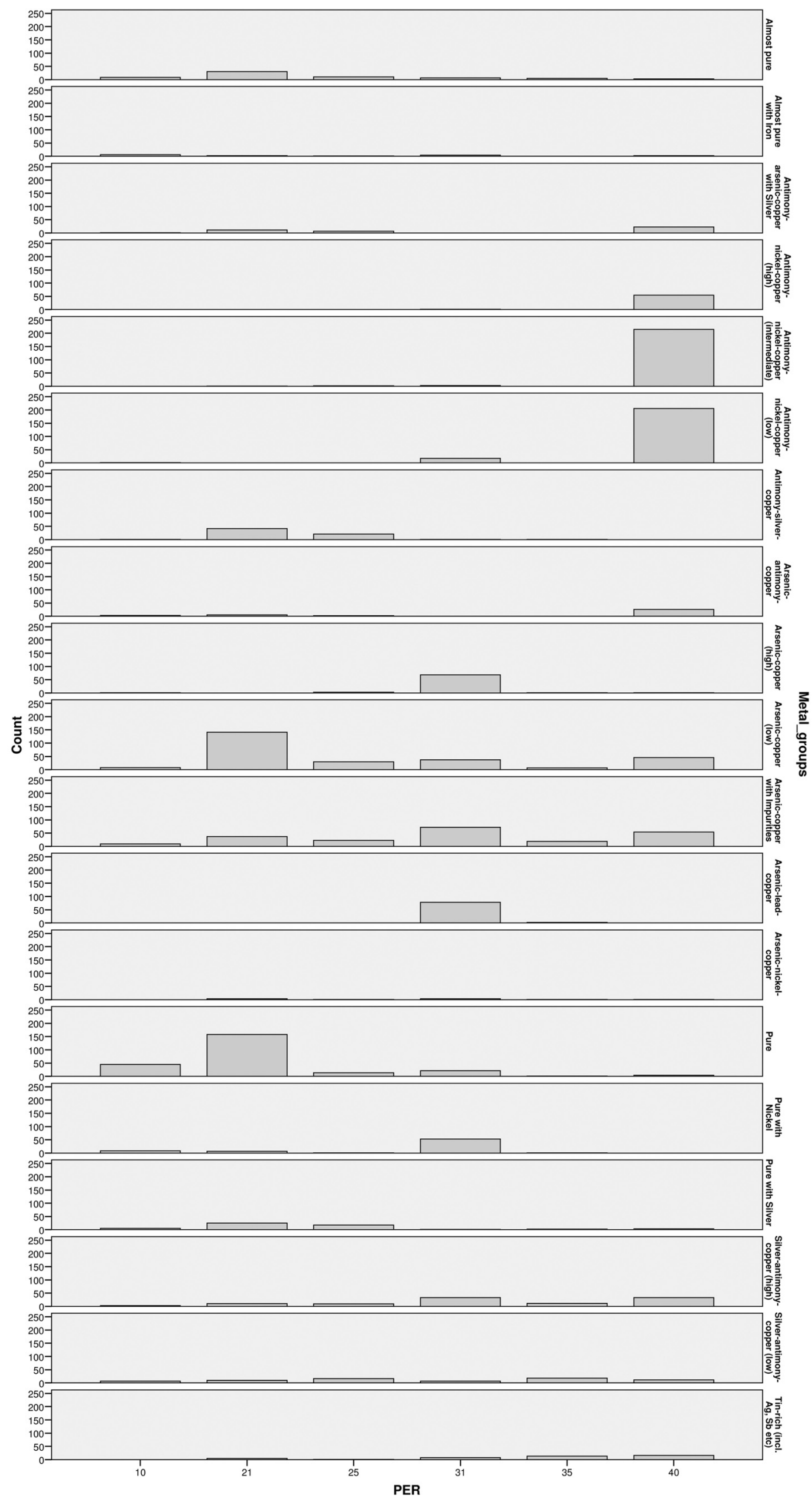

Figure 5. Bar charts showing the chronological distribution of the 19 metal groups (PER 10: before c. 4000 BC; PER 21: c. 4000-3500 BC; PER 25: c. 3500-2800 BC; PER 31: c. 2800-2300 BC [without Bell Beaker finds]; PER 35: only Bell Beaker related objects; PER 40: c. 2200-2000 BC). 
Figure 6. Scatter plot of the Principle Component Analysis on the entire database of 1943 trace element analyses; marking the 82 trace element analyses carried out on Bell Beaker $(\boldsymbol{\Delta})$ and on Non Bell Beaker finds $(\mathrm{O})$ and the regional distribution of the entire database (AREA: 103-105: central Germany; AREA 111-113: Bohemia; AREA 114-122 and 72: Moravia, Slovakia and Lower Austria; AREA 123-125: Hungary; AREA 51-66: southern Germany; AREA 67, 71 and 73: Switzerland and the alpine region; AREA 83-85: southern Poland [AREA-keys are used according to Krause 2003, 290-292]).

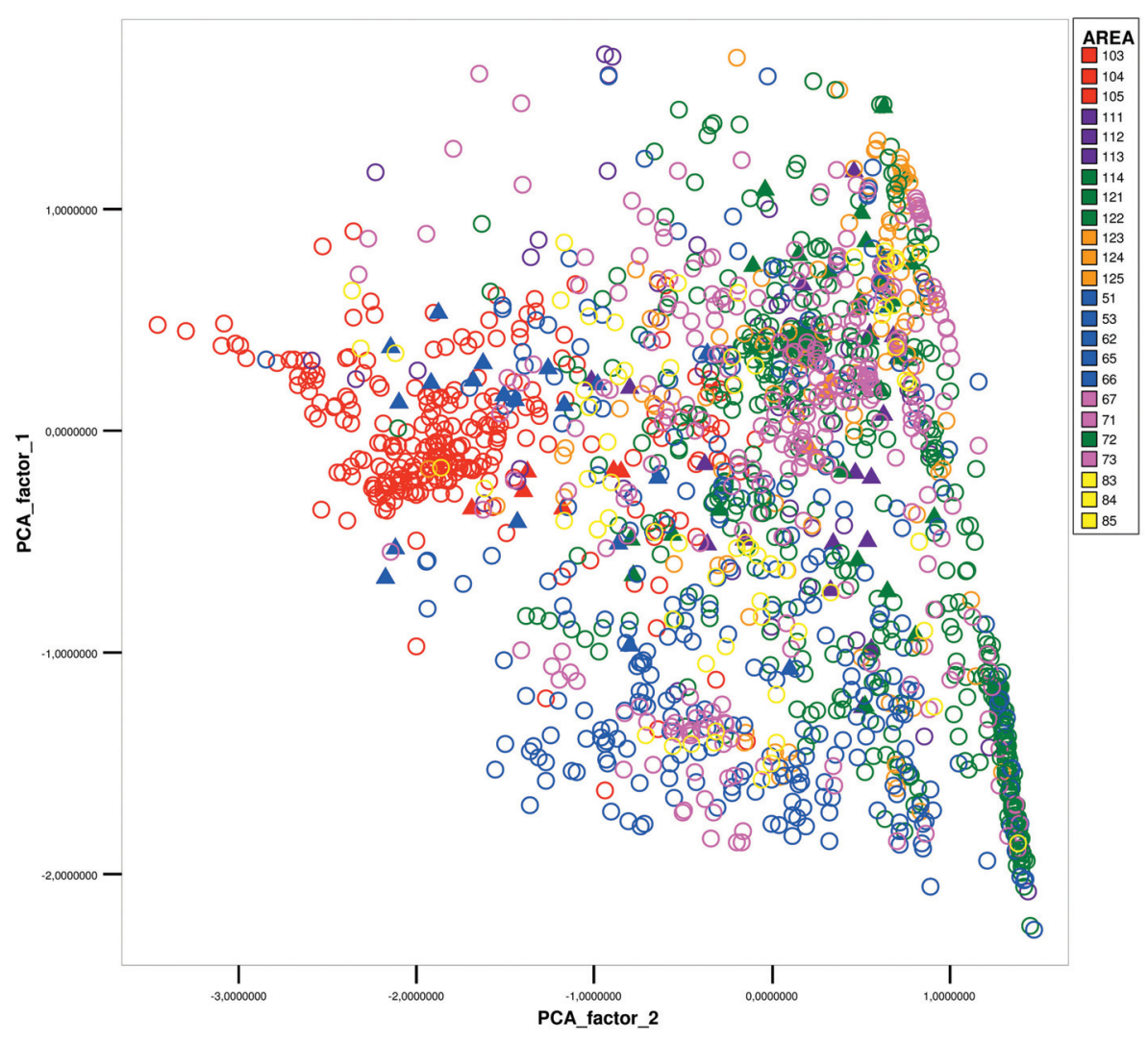

found, not only in Bell Beaker, but also in copper artefacts of Corded Ware or the earliest Bronze Age contexts.

With reference to the entire database of Chalcolithic trace element analyses it is obvious that metal objects of the Eastern Bell Beaker group do not consist of one specific type of copper. All types of copper that have been used for Bell Beaker objects are also employed in other periods (PER). Not only did they use fahlore-copper, they also used pure, almost pure and arsenic-copper (low) which is typical of earlier periods. Whilst copper types with low levels of impurities were used during all parts of the Chalcolithic, those with higher impurity levels have been used frequently until after c. 2800 BC. Artefacts of antimony-nickel-coppers were chiefly from contexts of the Straubing or Nitra group or from the cemetery of Singen am Hohentwiel (all PER 40), but these copper types were not used for Bell Beaker objects.

The scatter plot (Figure 6) shows that Bell Beaker finds of similar copper types do not cluster at any particular section. As Matuschik (2004, 293 ff.) also pointed out, in southern Germany it was particularly dealt with lead- and bismuthrich copper - but not exclusively in these areas. In general it can be said that there is an East-West discrepancy. Based on the database of this study, significant bismuth, lead and nickel concentrations are found not only Bavarian or south-western German Bell Beaker finds (AREA 62 and 66), but also in samples from the Middle-Elbe-Saale region (AREA 103) and the Czech Republic (AREA 111-114)9.
However, the significance of southern and central German (AREA 51-66 and 103-105) is reflected by central German Corded Ware copper as well. In this case we suppose a local copper type in the $3^{\text {rd }}$ millennium $\mathrm{BC}$. These artefacts are chiefly made of lead- and bismuth-rich arsenical fahlorecoppers (i.e. arsenic-copper [high], arsenic-lead-copper and arsenic-copper with impurities). Since these are also found in other areas it was probably distributed. In spite of this, it is not possible to identify a specific type of copper used only by metal workers or for artefacts of the Eastern Bell Beaker group, because all types of "Bell Beaker copper" were also used for other artefacts found in other regions and in non-Bell-Beaker contexts. Figure 5 clearly displays that the earlier discussed difference of Bell Beaker metal used in the western and eastern areas of this study does not reflect a Bell Beaker specific metallurgy. Copper of similar compositions has been treated in various regions and by other archaeological groups.

In regard to the subject of this study, it was deduced that fahlore-metallurgy was not only used by Bell Beaker metallurgists, and that, at least in central Europe, the introduction of fahlore-copper is not exclusively connected to the emergence of the Bell Beaker phenomenon. We conclude

${ }^{9}$ The bismuth- and lead-rich objects are concentrated on the left side of the scatter plot. 
that technological advantages or access to special resources was not distinct to Bell Beaker users. The archaeological phenomenon that is defined as Eastern Bell Beaker group does not differ from other contemporary communities in consideration of a distinctive use of copper.

\section{Discussion}

To summarise the comparison of Bell Beaker metal with types of copper used in other archaeological groups, this study has clearly shown that there is no specific copper used only by Bell Beaker metal workers. Throughout central Europe the distribution of various types of copper used by Bell Beaker metallurgists coincides chiefly with the copper types of PER 31 (c. 2800-2300 BC). We can speak of metallurgical techniques generally used during both period 31 and 35 , but not exclusively used by any archaeological group. Accordingly, this study has clarified that metallurgy cannot be seen as both a "culture-defining" element and the chief reason for the spread of the Bell Beaker phenomenon in central Europe. In other areas this may be different. In Britain, for instance, where the appearance of the Beaker phenomenon was roughly contemporaneous with the adoption of the first metal objects, Bell Beaker using communities may have been more strongly connected to a specific metallurgy (cf. Needham 2002).

The comparison and interpretation of trace element analyses of Chalcolithic copper artefacts implies that - given the broad use of different types of copper - Bell Beaker metallurgists had access to several resources and were able to deal with those. In terms of metallurgical expertise, Bell Beaker communities in central Europe are not distinct from other archaeologically-evident communities, and were interacting with them. This reflects the Bell Beaker network not only in area-wide, but also in "cultural-" overlapping. The pan-European network of the Bell Beaker communities may have provided the foundation to acquire and trade copper and the far less common tin.

Indeed, the number of copper, gold and silver grave goods, along with graves containing metal workers' tools indicate, that metal played an important role for Bell Beaker users, at least in burial rites and religious beliefs. It seems that the differences that we determine between Corded Ware and Bell Beaker using communities is based more on burial rites or "religion" than on copper technology. The Eastern Bell Beaker group used these goods to display social or religious status in funeral practises.

There is no evidence to prove that Bell Beaker users were metal prospectors, workers or traders, nor that they had special metallurgical expertise. Access to special resources or technology cannot be ascertained, and the compositions of Bell Beaker metal artefacts do not show indications of an exceptional role in distributing fahlore-copper by its carriers. Fahlore-copper had already been in use at an earlier date. In contrast, "Bell Beaker metallurgy" is part of the general metallurgical traditions of the $3^{\text {rd }}$ millennium $\mathrm{BC}$.

\section{Acknowlegdement}

I want to express my appreciation to my supervisors Dr. M. S. Midgley and Dr. A. Sheridan and to Prof. Dr. Chr. Strahm for their great support and invaluable advice. Furthermore, I am indebted to the statistician Frances Provan (Convenor of the Statistical Systems Support team at the University of Edinburgh) for her outstanding support and helpful advice. I am thankful for the financial support to my studies given by the Dr. Margaret Stewart Bequest, the Abercromby Fund and the School of History, Classics and Archaeology at the University of Edinburgh. Last, but not least, I am very grateful to Dr. R. R. Wiermann (Museum Bernburg) who provided several trace element analyses from central Germany for this study.

\section{References}

ARCHBUTT, S. L., PRYTHERCH, W. E. 1931: Investigation of the Effects of Impurities on Copper. Part VII. - The Effect of Antimony on Copper. Part VIII. - The Combined Effect of Antimony and Arsenic on Copper. Journal of the Institute of Metals XLV/1, 265-305.

ARCHBUTT, S. L., PRYTHERCH, W. E. 1937: Effect of Impurities in Copper, London.

BACHER, J., WENZIG, K. and VOGLER, M. 2004: SPSS TwoStep Cluster - A First Evaluation. Arbeits- und Diskussionspapiere 2004-2. Lehrstuhl für Soziologie der Friedrich-Alexander-Universität Erlangen-Nürnberg.

http://www.opus.ub.uni-erlangen.de/opus/volltexte/2004/81/pdf/a_04-02. pdf [04/04/2009].

BARTELHEIM, M., ECKSTEIN, K., HUIJSMANS, M., KRAUSS, R., PERNICKA, E. 2002: Kupferzeitliche Metallgewinnung in Brixlegg, Österreich. In: Bartelheim, M., Krause, R., Pernicka, E. (Eds.): Die Anfänge der Metallurgie in der Alten Welt. Forschungen zur Archäometrie und Altertumswissenschaft. Vol. 1., Rahden, 33-82.

BAXTER, M. J. 2003: Statistics in Archaeology, London.

BENZ, M., GRAMSCH, A., WIERMANN, R. R. 1998: Rethinking Bell Beakers. In: Benz, M., van Willigen, S. (Eds.): Some New Approaches to the Bell Beaker "Phenomenon". Lost Paradise...? Proceedings of the 2nd Meeting of the „Association Archéologie et Gobelets”. Feldberg (Germany), $18^{\text {th }}-20^{\text {th }}$ April 1997. BAR 690, Oxford, 181-185.

BERTEMES, F., HEYD, V. 2002: Der Übergang Kupferzeit/Frühbronzezeit am Nordwestrand des Karpatenbeckens - Kulturgeschichtliche und paläometallurgische Betrachtung. In: Bartelheim, M., Krause, R., Pernicka, E. (Eds.): Die Anfänge der Metallurgie in der Alten Welt. The Beginnings of Metallurgy in the Old World. Forschungen zur Archäometrie und Altertumswissenschaft. Vol. 1, Rahden, 185-228.

BERTEMES, F., SCHMOTZ, K., THIELE, W.-R. 2000: Das Metallurgengrab 9 des Gräberfeldes der Glockenbecherkultur von Künzing, Lkr. Deggendorf. In: Chytráček, M., Michálek, J., Schmotz, K. (Eds.): Archäologische Arbeitsgemeinschaft Ostbayern/West- und Südböhmen - Archeologická pracovní skupina východni Bavorsko/západni a jižní Čechy. 9. Treffen 23. bis 26. Juni 1999 in Neukirchen b. Hl. Blut, 53-60.

BUDD, P. 1991: A Metallographic Investigation of Eneolithic Arsenical Copper. Determination of the Manufacturing Processes of Early Prehistoric Arsenical Copper Artefacts by Microstructural Analysis based on a Re-evaluation of the Mechanical Properties of Copper-arsenic Alloys. PhD-thesis. Deposited: University of Bradford.

BUTLER, J. J., van der WAALS, J. D. 1966: Bell Beakers and Early Metalworking in the Netherlands. Paleohistoria 12, 42-139.

CHARLES, J. A. 1967: Early arsenical Bronzes - A metallurgical view. American Journal of Archaeology 71/1, 21 - 26.

CHILDE, V. G. 1929: The Danube in Prehistory, Oxford.

CHIU, T., FANG, D., CHEN, J., WANG, Y., JERIS, C. 2001: A Robust and Scalable Clustering Algorithm for Mixed Type Attributes in Large Database Enviroment. In: Provost, F., Srikant R. (Eds.): Proceedings 
of the seventh ACM SIGKDD International Conference on Knowledge Discovery and Data Mining. New York, 263-269.

CRADDOSK, P. T. 1995: Early Metal Mining and Production, Edinburgh. DIES, K. 1967: Kupfer und Kupferlegierungen in der Technik, Berlin.

FRÁNA, J., JIRÁŇ, L., MAŠTALKA, A., MOUCHA, V. 1995: Artefacts of copper and copper alloys in prehistoric Bohemia from the viewpoint of analyses of element composition. Památky archeologické Supplementum $3,125-205$.

FREUDENBERG, M. 2009: Steingeräte zur Metallbearbeitung Einige neue Aspekte zum spätneolithischen und frühbronzezeitlichen Metallhandwerk vor dem Hintergrund des schleswig-holsteinischen Fundmaterials. Archäologisches Korrespondenzblatt 39/3, 341-359.

FRIEDMAN,A. M., CONWAY, M., KASTNER, M., MILSTED, J., METTA, D., FIELDS, P. R., OLSEN, E. 1966: Copper Artifacts: Correlation with Source Types of Copper Ores. Science 152, 1504-1506.

HÁJEK, L. 1966: Die älteste Phase der Glockenbecherkultur in Böhmen und Mähren. Památky archeologické 57, 210-241.

HANSON, D., FORD, G. W. 1924: Investigation of the Effects of Impurities on Copper. Part II. - The Effect of Iron on Copper. Journal of the Institute of Metals XXXII/2, 335-365.

HANSON, D., FORD, G. W. 1927: Investigation of the Effects of Impurities on Copper. Part V. - The Effect of Bismuth on Copper. Journal of the Institute of Metals XXXVII/1, 169-181.

HEYD, V. 2007: Families, Prestige Goods, Warriors \& Complex Societies: Beaker Groups of the $3^{\text {rd }}$ Millennium cal BC along the Upper \& Middle Danube. Proceedings of the Prehistoric Society 73, 327-379.

HOFMAN, H. O. 1924: Metallurgy of Copper, New York/London.

JUNGHANS, S., SANGMEISTER, E., SCHRÖDER, M. 1960: Metallanalysen kupferzeitlicher und frühbronze zeitlicher Bodenfunde aus Europa, Berlin.

JUNGHANS, S., SANGMEISTER, E., SCHRÖDER, M. 1968 \& 1974 Kupfer und Bronze in der frühen Metallzeit Europas. Vol. 1 - 4, Berlin.

JUNK, M. 2003: Material properties of copper alloys containing arsenic antimony and bismuth. The material of Early Bronze Age ingot torques. $\mathrm{PhD}$-thesis at the Technische Universität Bergakademie Freiberg http://www.cez-archaeometrie.de/dipl-diss/diss-junk-2003.pdf [11.05.2007]

KIENLIN, T. L. 2008: Frühes Metall im nordalpinen Raum. Eine Untersuchung zu technischen und kognitiven Aspekten früher Metallurgie anhand der Gefüge frühbronzezeitlicher Beile. Universitätsforschungen zur prähistorischen Archäologie 162, Bonn.

KLASSEN, L., MATUSCHIK, I., PERNICKA, E., RASSMANN, K. 1998: Die frühesten Metallfunde in Mecklenburg-Vorpommern im Lichte neuer Metallanalysen. Vom Endneolithikum bis zur Bronzezeit. Jahrbuch der Bodendenkmal pflege in Mecklenburg-Vorpommern 1997-45, 41-67.

KRAUSE, R. 1988: Die endneolithischen und frühbronzezeitlichen Grabfunde auf der Hochterrasse von Singen am Hohentwiel, Stuttgart.

KRAUSE, R. 2003: Studien zur kupfer- und frühbronzezeitlichen Metallurgie zwischen Karpatenbecken und Ostsee (incl. CD-ROM "Stuttgarter Metallanalysen Datenbank"), Rahden.

KUNA, M., MATOUŠEK, V. 1978: Měděná industrie kultury zvoncovitých pohárů ve střední Evropě - Das Kupferinventar der Glockenbecherkultur in Mitteleuropa. Praehistoria 7, 65-89.

LECHTMAN, H. 1996: Arsenic Bronze. Dirty Copper or Chosen Alloy? A View from the Americas. Journal of Field Archaeology 23/4, 477-514.

LIVERSAGE, D. 1994: Interpreting composition Patterns in Ancient Bronze: The Carpathian Basin, Acta Archaeologica 65, 57-134.

MATUSCHIK, I. 1998: Kupferfunde und Metallurgie-Belege, zugleich ein Beitrag zur Geschichte der kupferzeitlichen Dolche Mittel-, Ost- und Südeuropas. In: Mainberger, M. (ed.): Das Moordorf von Reute. Steinzeit in Oberschwaben, Staufen i. Br. 207-261.

MATUSCHIK, I. 2004: Kupfer der Glockenbecherkulturim Nordalpengebiet. Zur endneolithischen Kupfergewinnung in den nordöstlichen Alpen. In Weisgerber, G., Goldenberg, G. (Eds.): Alpenkupfer - Rame delle Alpi. Anschnitt, Beiheft 17, Bochum, 285-302.

McKERELL, H, R. F. TYLECOTE, R. F. 1972: The Working of CopperArsenic Alloys in the Early Bronze Age and the Effects on the Determination of Provenance. Proceedings of the Prehistoric Society 38, 209-218.
METZINGER-SCHMITZ, B. 2004: Die Glockenbecherkultur in Mähren und Niederösterreich. Typologische und chronologische Studien auf dem Hintergrund der kulturhistorischen Abläufe während der späten Kupferzeit im Untersuchungsgebiet. Mit einem paläometallurgischen Exkurs. PhD-thesis at the University of Saarland http://scidok.sulb.uni-saarland.de/volltexte/2004/320/ [22.07.2006].

MOESTA, H. 2004: Bermerkungen zu bronzezeitlichen Metallen mit hohem Gehalt an Arsen und/oder Antimon, den sog. Fahlerzen, In: Weisgerber, G., Goldenberg, G. (Eds.): Alpenkupfer - Rame delle Alpi. Anschnitt, Beiheft 17, Bochum, 269-272.

NEEDHAM, S. 2002: Analytical Implications for Beaker Metallurgy in North-West Europe. In: Bartelheim, M., Krause, R., Pernicka, E. (Eds.): Die Anfänge der Metallurgie in der Alten Welt. Forschungen zur Archäometrie und Altertumswissenschaft. Vol. 1., Rahden, 99-133.

OTTAWAY, B. S. 1978: Frühes Arsenkupfer im nordalpinen Raum. Thracia Praehistorica Supplimentum 3, 177-188.

OTTAWAY, B. S. 1982: Earliest Copper Artefacts of the Northalpine Region: Their Analysis and Evolution, Bern.

OTTO, H., WITTER, W. 1952: Handbuch der ältesten vorgeschichtlichen Metallurgie in Mitteleuropa, Leipzig.

PERNICKA, E. 1995: Gewinnung und Verbreitung der Metalle in prähistorischer Zeit. Jahrbuch des Römisch Germanischen Zentralmuseums 37/1, 1990, 21-129.

PERNICKA, E. 1999: Trace Element Fingerprinting of Ancient Copper. A Guide to Technology or Provenance?. In: Young, S. M. M., Pollard, A. M., Budd, P., Ixer, R. A. (Eds.): Metals in Antiquity. BAR S792, Oxford, $22-32$

ROBERTS, B. W., THORNTON, C. P., PIGOTT, V. C. 2009: Development of metallurgy in Eurasia. Antiquity 83, 1,012-1,022.

ROVIRA LLORENS, S., DELIBES de CASTRO, G. 2005: Beaker Metallurgical Technology in the Iberian Peninsula. In: García Martínez de Lagrán, I., Garrido Peña, R., Rojo Guerra, M. A. (Eds.): El Campaniforme en la Península Ibérica y su Contexto Europeo. Bell Beakers in the Iberian Peninsula and their European Context. Valladolid, 513-521.

SHENNAN, S. 1997: Quantifying Archaeology. Second ed., Edinburgh.

SMART, J. S. 1970: The Effect of Impurities in Copper. In: Butts, A. (Ed.): Copper. The Science and Technology of the Metal, its Alloys and Compounds. New York, 410-416.

SPERL, G. 1975: Metallurgische Untersuchungskriterien metallischer Funde der Kupfer- und Bronzezeit Europas. In: Jeglitsch, F., Petzow, G. (Eds.): Fortschritte der Metallographie, Praktische Metallographie 4. Stuttgart, 3-26.

SPINDLER, K. 1971: Zur Herstellung der Zinnbronze in der frühen Metallurgie Europas. Acta Praehistorica et Archaeologica 2, 199-253.

STANIASZEK, B. E. P., NORTHOVER, J. P. 1982: The Properties of Leaded Bronze alloys. In: Proceedings of the 22nd Symposium on Archaeometry, University of Bradford March 30 $0^{\text {th }}$-April $3^{\text {rd }}$ 1982, Bradford, 262-272.

STRAHM, C., HAUPTMANN, A. 2009: The Metallurgical Developmental Phases in the Old World. In: Kienlin, T. L., Roberts, B. W. (Eds.): Metals and Societies. Studies in honour of Barbara S. Ottaway. Universitätsforschungen zur prähistorischen Archäologie 169. Bonn, 116-128.

Van der LINDEN, M. 2007: What linked the Bell Beakers in the third millennium BC Europe? Antiquity 81, 343-352.

WANG, Q., OTTAWAY, B. S. 2004: Casting Experiments and Microstructure of archaeologically relevant Bronzes. BAR 1331, Oxford.

ZHANG, T., RAMAKRISHNAN, R., LIVNY, M. 1996: BIRCH. An Efficient Data Clustering Method for Very Large Databases. In: Jagadish, H. V. (Ed.): Proceedings of the 1996 ACM SIGMOD International Conference on Management of Data (Montreal). New York, 103-114.

ZHANG, T., RAMAKRISHNAN, R., LIVNY, M . 1997: BIRCH. A new Data Clustering Algorithm and its Applications. Data Mining and Knowledge Discovery 1, 141-182.

ZIMMERMANN, T. 2007: Die ältesten kupferzeitlichen Bestattungen mit Dolchbeigabe. Monographien des Römisch-germanischen Zentralmuseums 71, Mainz. 
